\title{
武庫川流域圏における有機物資源リサイクルシ ステムの構築と評価
}

\author{
栗栖 雅宜 $^{1} \cdot$ 藤田 壮 $^{2} \cdot$ 盛岡 通 $^{3}$ \\ 1大阪大学大学院工学系研究科 環境工学専攻 E-mail:kurisu@ecolonia.env.eng.osaka-u.ac.jp \\ 2博士（工学） 東洋大学工学部 環境建設工学 教授 E-mail;fujita@eng.toyo-u.ac.jp. \\ ${ }^{3}$ 工学博士 大阪大学大学院工学研究科 環境工学専攻 教授 E-mail:morioka@env.eng.osaka-u.ac.jp
}

\begin{abstract}
自然共生型の流域管理を行っていく上で, 物質循環を制御することは重要な意味を持つ. 本研究では循 環制御の対象として有機物資源を取り上げ，武庫川流域圈をケーススタディの対象として有機物資源リサ イクルシステムの構築を支援する方法を提案した. 具体的には地域特性に適合する有機物資源再資源化技 術の指標として量的指標, 質的指標, 需給指標の 3 つをあげ，それらの指標から示される資源循環区に対 して再資源化技術を導入することによる二酸化炭素排出量の削減効果を評価した. それによると, 適合度 分析により示される流域リサイクルシステムは，対象区域全域に画一的な単一の再資源化技術を導入した 場合よりも環境影響が少ないことが示された。これにより流域管理において, 地域特性を見た上で再資源 化施策を決定するプロセスを試行的に構築することができた.
\end{abstract}

Key Words : basin-wide management, organic waste, biomass, sutability analysis

\section{1. 研究の背景と目的}

流域圈で人間は, 水循環によって維持される自然生態 系からのサービスを長期間にわたって享受してきた. そ の一方で産業化と都市化に伴い人間活動が拡大してきた 結果，海面の埋立や污濁物質の排出などの大きな環境負 荷が流域内外にもたらされている.これらの事象が複雑 な相互作用を伴いつつ影響を及ぼし合うことにより赤潮 の発生や干潟の減少といった地域生態系が損なわれる状 況を招き, 人間社会が健全な都市生活を流域圈で将来に わたって持続可能な形でおこなっていくための不都合が 大きくなりつつある ${ }^{1)}$.

自然環境と共生し, 持続可能な流域圏の構築・管理を おこなうためには，有機系をはじめとする物質の循環を 持続可能な形で制御することが重要である. そのために は処理基盤の建設と高度化だけではなく, 物質回收領域 や再資源化施設立地点の再編, さらに社会的システムを 改変すること等も視野に入れて多様な政策プログラムを 流域特性に応じて統合的に設計・推進することが必要で ある.

そこで本研究では, 流域圈を流域の土地利用や産業 活動を面的に分布した形で捉えるアプローチを支える ための空間単位として定義し, その圈域での有機性物 質循環利用のための技術の選択肢を用意する. その上 で, 有機性廃棄物の発生特性と物質転換の効率, およ び再資源化された技術の需要特性を考慮して, 物質循
環効率を高める流域圈での有機性物質循環システム設 計の方針を決定する論理プロセスを構築する.

\section{2. 有機物循環の既存研究の類型化}

\section{（1）有機物循環技術の適用に関する研究の類型}

有機系廃革物の循環に関する研究を対象とする廃棄 物種類及び再資源化技術のカテゴリーにより分類する. 増田ら (2002） ${ }^{2)}$ らは単一種の廃棄物を対象として単 一の再資源化技術を適用した場合の噮境負荷削減効果 に関する研究をおこなっている. すなわち, 家庭生ご みを対象として堆肥化による二酸化炭素排出量削減効 果を種々のシナリオに対して検討をおこっている. 次 に平井らの研究 (2002) では ${ }^{3)}$, 単一種の廃棄物に対 して複数の再資源化技術を導入した場合の効果を比較 している. 標準生ごみについて, 焼却埋立, メタン発 酵一残渣焼却, メ夕ン発酵一残渣堆肥化, 堆肥化の 4 種の再資源化技術を適用した効果を地球温暖化, 酸性 化, 埋立地消費, 有害物質による健康影響の 4 つの影 響領域に対して評価を行っている. これに対して盛岡 ら (2002） ${ }^{4)}$ は神戸東部第四工区食品コンビナートか ら発生する多様な食品廃棄物を対象として, その循環 システムを変化させることによるメタン発酵の効果を 検討している. また松本ら（2000）5は，複数の有機 性廃棄物に対して, 多様な再資源化技術を適用した際 
の環境影響評価を行っており，ディスポーザーにより 㞛芥と下水污泥を統合的に扱うことを想定して, 処理 後にコンポスト化あるいは乳酸化する場合の環境影響 評価を行っている.

以上の有機物循環に関する研究を表 1 のように整理 する.

表 1 有機物循環に関する研究の整理

\begin{tabular}{|c|c|c|c|}
\hline & \multicolumn{2}{|c|}{ 対象廃畗物種数 } \\
\hline & & 単- & 複数 \\
\hline & 単 & 増田ら (2002） ${ }^{2)}$ & 盛岡ら (2002) 4$)$ \\
\hline 術資 & 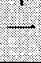 & 家庭生ごみを堆肥化 & $\begin{array}{c}\text { 複数種の食品廃棄物 } \\
\text { をメタン発酵 }\end{array}$ \\
\hline 数化 & 袙 & 平井ら $(2002)^{3)}$ & 松本ら (2000) 5$)$ \\
\hline 技 & 数 & $\begin{array}{c}\text { 標準生ごみをメタン } \\
\text { 発酵及び堆肥化 }\end{array}$ & $\begin{array}{c}\text { 屍芥と下水污泥を堆 } \\
\text { 肥化及び乳酸化 }\end{array}$ \\
\hline
\end{tabular}

（2）施設立地の環境影響評価を行った既存研究 地域特性との適合性から見た施設の面的配置に関す る研究として, 原沢ら (1992）6) は独自に開発した流 域管理システムの適用例として, 生活排水処理方式 (下 水道や合併浄化槽) の地域的な組合わせや緊急度の高
い地域の選定などの問題に対して有効な分散度といっ た指標を提案している．また近年はその操作性の高さ から GIS (地理情報システム)が多く利用されている. 例えば荒巻ら（2000）7) は CGS と清掃工場廃熱を利 用した地域冷暖房システム (DHC) を東京都区部の各 $250 \mathrm{~m}$ ッシュにおいて評価し,そのシステムを導入し た場合の二酸化炭素排出削減効果を都区部全体で推定 している．また一瀬ら（2000）8 は下水から得られ る温熱エネルギーを都市内で有効に再利用するための 地域熱供給施設の立地について，専用に開発された GIS により,東京 23 区内の全 11 下水処理区を対象と した温熱需要と熱供給事業における排熱利用とのバラ ンスに対する解析を行っている.（表 2)

表 2 地域特性からみた施設配置に関する研究

\begin{tabular}{|c|c|c|}
\hline 研究者 & 空間配置検討旅設 & 特徵 \\
\hline $\begin{array}{c}\text { 荒巻ら } \\
(2000)\end{array}$ & CGプラント & エネルギー需要を元にシステム構築 \\
\hline 一ノ瀬ら & ヒートポンプ施設 & $\begin{array}{c}\text { 熱の需給関係やHP1基当たりの利用可 } \\
\text { 能熱量からDHC事業適正評価 } \\
(2000)\end{array}$ \\
\hline $\begin{array}{c}\text { 原沢ら } \\
(1992)\end{array}$ & 生活排水処理施設 & 分散度を定義 \\
\hline
\end{tabular}

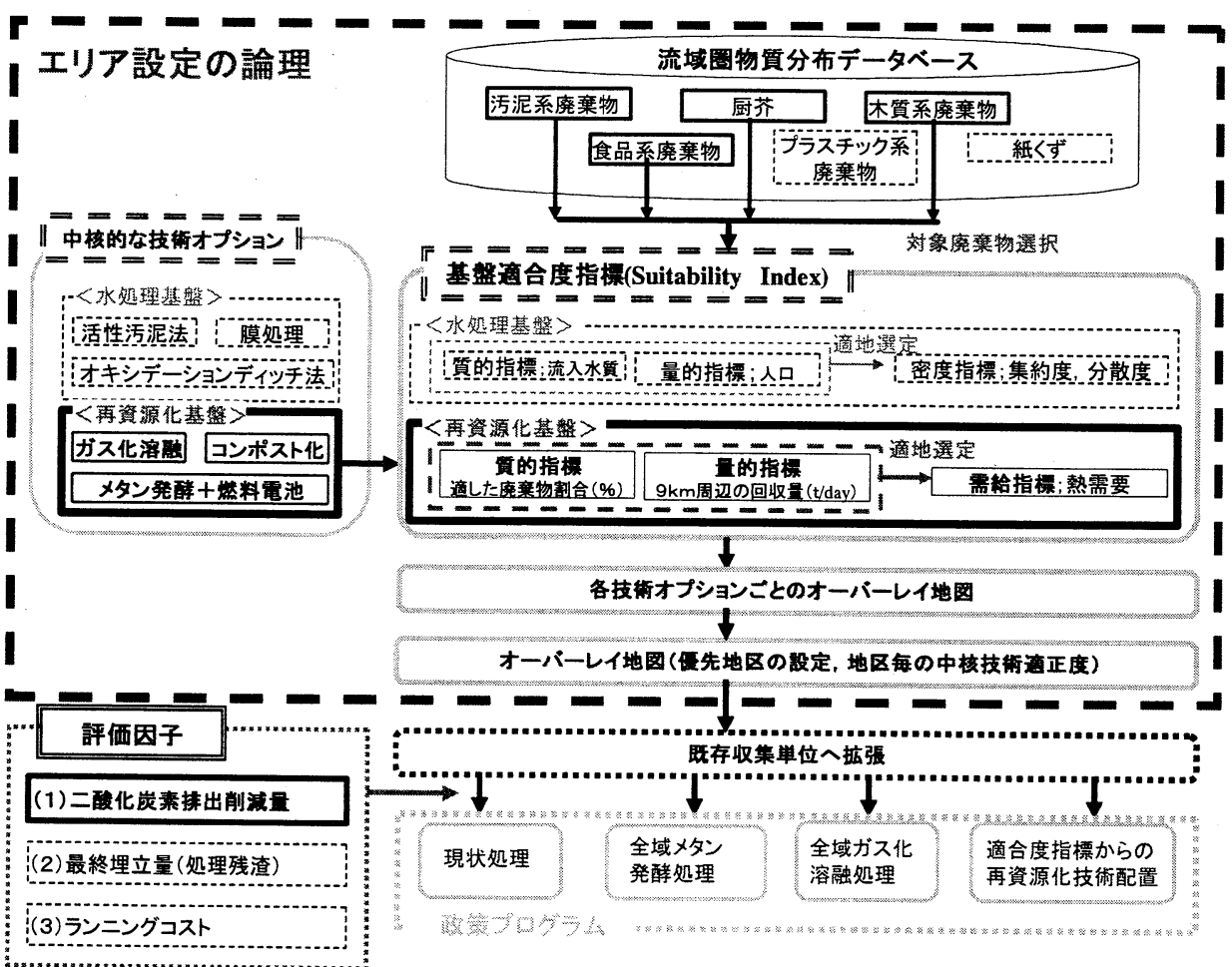

図 1 研究のフロー 


\section{3. 基盤適合度指標を用いた循環システムの設計}

本研究では複数の有機系廃棄物や代替的な循環技術 を視野に入れたうえで, 都市や農村, あるいは上流域・ 下流域といった多様な特徵を包含する流域圏において 発生する有機性廃棄物の特性と分布に応じて適正に循 環制御システムを計画する論理プロセスを構築するこ とをめざす. その際に対象とする有機性廃棄物として, 污泥, 食品廃棄物, 时芥, 木質廃棄物を挙げ, プラス チック系廃棄物や紙くず，シュレッダーダスト等は本 研究では対象としないこととした.

各地域の特性に応じた制御技術及び施設配置を選定

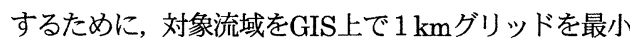
単位として区分し, 経済圈や行政圏に影響を受ける形 で捉えられる有機性廃棄物の発生量や性状を各グリッ ドに配分し，それを活用することによって効率的な制 御技術と地域特性との適合性を示す指標（基盤適合度 指標）を算定するプロセスを構築する. 次いで実際の 流域を対象として算定された指標にもとづいて，有機 系物質を循環するシステムの環境負荷の削減効果を定 量的に評価する.

（1）有機物偱環の技術システムの適合度評価プロセス 短中期的に実現が予想される, 有機物循環の技術オプ ションとして「メタン発醅と燃料電池の組合せ」「ガス
化溶融」「コンポスト化」を選定して，それぞれに質的 指標, 量的指標, 需給指標を定義して, その地区ごとの 算定によって，地域特性に応じた循環技術を選択する. 第一に質的指標と量的指標から，基盤の処理技術特性か らの適地を選定し，第二に需給指標により社会特性から のソーティングする. 各オプション技術に対してこのプ ロセスを適用し, その結果得られた技術導入の適地を才 一バーレイすることで, 再資源化技術ごとに整備の優先 候補地区が決定される. その候補地区をもとに，実際の 処理基盤網の整備状況を考慮した計画処理区を設定する ことにより，流域圏において循環技術ごとの適用エリア を決定する. そのうえで環境への影響を評価する. 以上 の作業フローを図 1 に示す.

\section{（2）基盤適合度指標の設計}

循環制御技術の地域特性との適合性を見る指標を設定 する. この指標には, 発生廃裹物量や廃棄物性状だけで はなく, 廃棄物発生密度や費用, あるいは地域生態系と の関連から純自然的な要素なども包括しているべきであ るが, 本研究ではこうした要素群の内, 発生する有機系 廃棄物性状（質的指標）, 発生廃棄物量（量的指標）, 再資源化物の需給関係（需給指標）を選択した.

質的指標として, 再資源化過程における効率に影響を 与える要素を取り上げる. 含水率は生物反応・物理化学 的反応を問わず大きな影響をもたらす要因であることか

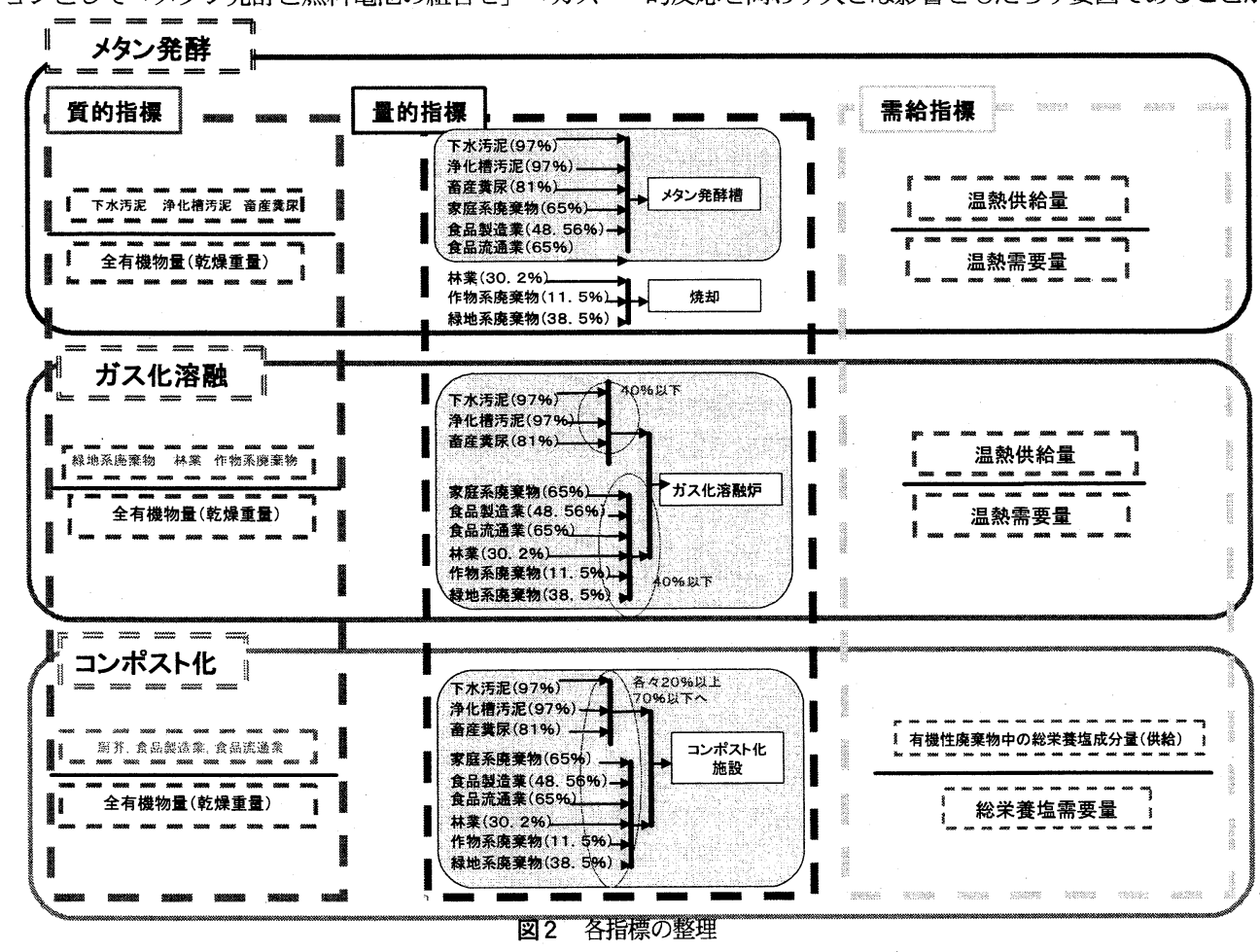


ら，質的指標として発生廃棄物の含水率に着目する. 再 資源化技術ごとの適正な含水率をもつ有機廃棄物が, 発 生状態で有する有機性廃妄物の全有機性廃棄物に占める 割合を乾燥重量で算定したものを質的指標として算定し た.

量的指標については，廃棄物に対して再資源化処理を 適用する上で, 処理量による規模効果も考慮して, 有機 系廃棄物の乾燥重量を設定した.

需給指標については，再資源化物が有効に利用され新 規資源を代替して初めて循環形成が意義を持つとの前提 で算定する. 有機性廃棄物の再資源化は, 循環制御とい う側面を持っていると同時に廃棄物処理の側面も有して いるため, 需要に応じた再資源化物供給量の変化には困 難さが伴う. また再資源化物の供給地点之需要地点との 距離が大きい場合, 遠方から供給することは非効率かつ 安定性に欠き, 経済的にも不利になる.したがって需給 指標としては, 需要と供給との空間的バランスを考えて 再資源化物供給量の需要量に対する割合として設定する.

なお, 各指標とも周辺 $9 \mathrm{~km}$ メッシュの属性を中心メ ッシュに帰属させることにより算定している. 以上の有 機物循環技術システムの適合度評価を行う手順を図 2 に 整理する。

\section{4. 有機性廃棄物再資源化技術の定義}

\section{(1)メタン発酵と㜣料電池の組合せ技術の算定手順}

本技術オプションは, 物質の小規模循環を支えるもの で, 現時点での技術的完成度はそれほど高くないが，将 来における最も有望なりサイクル技術として位置付けら れる. その効果の算定にあたつては, 既存研究9) を参考 にメタン発酵により発生する単位投入物質量当たりのバ イオガス発生量は, 投入物質中の固形物量におよそ比例 するものとして算定した. 発酵プロセスに必要なエネル ギ一については, 㕑芥や食品製造業由来の有機性廃棄物 などの低含水率廃棄物をメ夕ン発醅によって再資源化す るために前処理によってスラリー化することを想定する 10). 続いてメ夕ン発酵を行う際には発醳槽を加温する必 要があることから, 低含水率の廃棄物 (含水率 $90 \%$ 以下) に対しては高温メタン発醉, 高含水率の廃棄物 (含水率 90\%以上）に関しては中温メタン発酵法を行うものと仮 定してそれに応じた槽加温熱エネルギ一計上した. また メタン発醭を行った後の脱離液は, 窒素やリンが豊富で あり水域における富栄養化現象などを考えると十分に除 去する必要がある. そこで後処理としての水処理に必要 なエネルギーも考慮することにする ${ }^{10)}$.メ夕ン発醏によ り得られる残渣は通常コンポスト化が行われることもあ
り，循環形成にさらに貢献することが可能であるが，コ ンポストの需要が限定され余剩に製造してしまう事例も 多く, また本研究では単一の再資源化技術の効果を算定 するものであるから, 残渣は脱水の後焼却されるものと して算定した.

図3にメタン発酵システムのフローを示す．以上のプ 口セスを経て生成されるメタンガスを中心とするバイオ ガスを近年発展の著しい燃料電池に供給することにより, 電力及び温熱を供給するものとする.

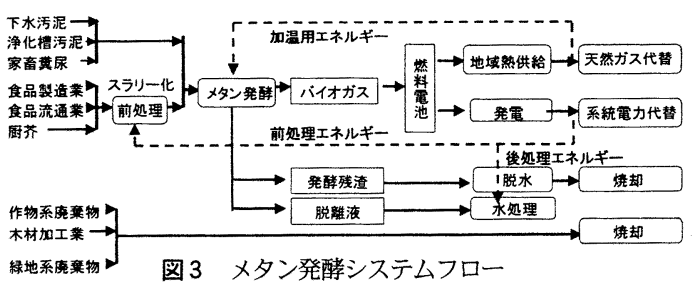

表 $3 \times$ タ発醘技術諸元

\begin{tabular}{|c|c|c|}
\hline 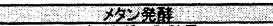 & 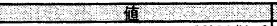 & 昰黄 \\
\hline ハイイオスス発熱重 & $23 \mathrm{MJ} / \mathrm{Nm} 3$ & 11) \\
\hline 矮料電池効率 & 電力効率 $38 \%$ ，鶖効率43\% & 12) \\
\hline メタン発醉槽加温エネルギー(中温) & $100 \mathrm{MJ} / \mathrm{t} *$ & 13) \\
\hline メ多発醏槽加温エネルギー(高温) & $326.57 \mathrm{MJ} / \mathrm{t}$ & 14) \\
\hline 前処理エネルギー & $85 \mathrm{kWh} / \mathrm{t}$ & 10) \\
\hline 水処理エネルギー & $56.7 \mathrm{kWh} / \mathrm{t}$ & 10) \\
\hline 残港排出エネルギー & $3.84 \mathrm{kWh} / \mathrm{t}$ & 10) \\
\hline 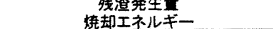 & $\begin{array}{r}0.02 \mathrm{t} / \mathrm{t} \\
150 \mathrm{kWh} / \mathrm{t}\end{array}$ & 15) \\
\hline
\end{tabular}

\section{（2）ガス化溶融技術適用の算定手順}

ガス化溶融に関しては, 下水污泥や浄化槽污泥など高 含水率廃棄物を処理する際には含水率を $40 \%$ まで低減 させた上でガス化溶融炉に投入することを仮定して， あ らかじめ含水率を低減させておくことによりガス化溶融 の効率を改善できるとの前提に立つ. 含水率を低減させ る工程に 2 段階を設定しており, 含水率 $80 \%$ 以上のも のを含水率 $80 \%$ まで低下させるためには脱水工程を, 含水率が $80 \%$ 以下のものを含水率 $40 \%$ まで低下させ るためには乾燥工程を導入することとしている. 脱水工 程の工ネルギーは花木らの值 ${ }^{10)}$ を用い, 乾燥工程の工 ネルギーは乾燥機勃率を $60 \%$ として計算した. この他 にガス化溶融処理自体に必要な電力も考慮して計算を行 った. 廃棄物を熱分解ガス化することによって発生する 燃焼ガスをガスエンジンに投入することによって電力及

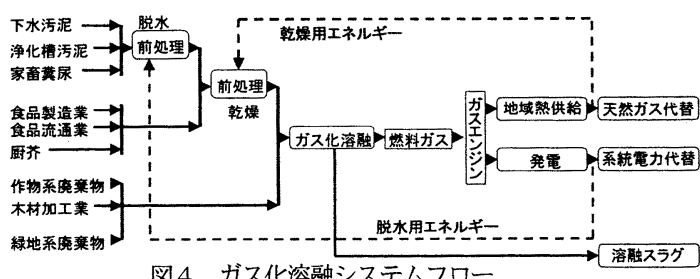

図4 ガス化溶融システムフロー 
び温熱を供給するものとする. 尚, 燃焼ガスの有する工 ネルギー量を投入廃棄物の低位発熱量から計算した. 図 4 にガス化溶融システムのフローを示す.

表4 ガス化溶融技術諸元

\begin{tabular}{|c|c|c|}
\hline ガス化溶跬 & 值 & 出典 \\
\hline ガスエンジン発電效率 & 電力効率37\%, 熱効率29\% & 16) \\
\hline ガス化消費電力 & $150 \mathrm{kWh} / \mathrm{t}$ (投入 $) *$ & 15) \\
\hline 污泥脱水消費電力 & $576 \mathrm{MJ} / \mathrm{t}$ & 17) \\
\hline 乾燥機効率 & $60 \%$ & 18) \\
\hline 絶対乾燥污泥比熱 & 0.6 & 18) \\
\hline 蒸発温度 & $70^{\circ} \mathrm{C}$ & 18) \\
\hline 流入ケ一キ温度 & $20^{\circ} \mathrm{C}$ & 18) \\
\hline
\end{tabular}

*ガス化溶融の必要電力は, 焼却段階の必要電力で代用した

\section{（3）コンポスト技術の算定手順}

コンポストの需要量としては, 土地利用ごとに算定 した肥料成分吸収量だけを考えればよいのではなく， 土壤に吸着され不活性化する又は微生物に餌として取 り込まれる等により土壌に残存するもの, 微生物に分 解され土壌から放出されるもの(脱窒が該当), 降雨など により流出，溶脱する場合などを考慮に入れる. 吸収 される割合 (利用率) は, 作物の根の活力や量, 施肥 方法，肥料の製剤形態などにより大きく異なるが，本 研究では肥料成分の利用率を窒素 $50 \%$, り 酸 $15 \%$, カリウム $60 \%$ と仮定した ${ }^{19)}$. さらに現在の化学肥料 による栄養素を全量堆肥による栄養素に転換すること は現実的ではないため，栄養素の $50 \%$ を堆肥により 代替するものと仮定した ${ }^{19)}$. コンポスト製造時におけ る窒素揮散率は $30 \%$ と仮定した ${ }^{19)}$. またコンポスト 製造時のエネルギー消費量も考慮した. 図 5 にコンポ ストシステムの設定フローを示す. コンポスト化に関 しては, 3 大栄養素である窒素, リン, カリウムを供 給可能であるとした.

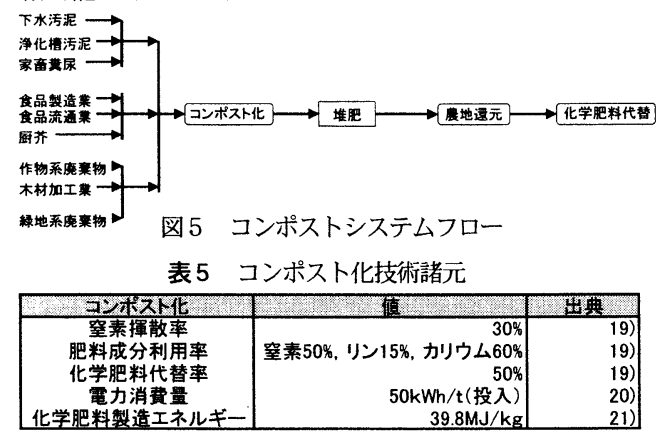

\section{5. 武庫川流域圏におけるケーススタディ}

兵庫県の武庫川流域圏を対象として, 有機系物質循 環技術の適合度を算定し, 流域圏での効率的な有機物 循環の整備の方針を構築した. その後有機物循噮施策 の環境効果の算定を行った.

\section{（1）武庫川流域圈の特徵}

武庫川流域は兵庫県の東部に位置する流域面積 $496 \mathrm{~km}^{2}$, 流路延長 $260 \mathrm{~km}$ の本川と 45 の支川・小支川 からなる二級河川で，同流域は尼崎市，西宮市，宝塚 市, 伊丹市, 神戸市北区, 三田市, 篠山市, 猪名川町, 大阪府能勢町の 6 市 1 区 2 町の, 約 150 万人の流域人口を 数える.

武庫川流域は過去20年間で兵庫県の県内総生産の約 $30 \%$ を占めており, 兵庫県において経済的に重要な部 分を担っている. 過去 20 年間で平均約 $3 \%$ の経済成長を 続けてきたが, 最近の 5 年間はマイナス成長となってい る. その産業構造はほぼ第2次産業と第3次産業とから 構成されている.

武庫川流域は上下流に1箇所ずつ流域下水道が整備 されており，1976年に武庫川下流流域下水道が，1985 年に武庫川上流流域下水道が供用開始されている. ま た処理に伴い発生する下水污泥（生污泥）は下流に位 置する兵庫東エースセンター(1989年供用開始)で, 焼 却処理されている. 尼崎沖の広域最終処分場フエニッ クスに近接しており, 廃棄物の多くは焼却, 埋立て処 分されている.

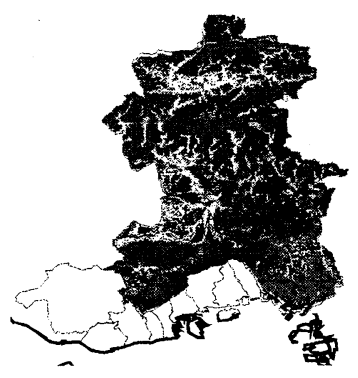

図 6 対象流域圏の土地利用状況

有機性廃棄物発生量推定については, 筆者ら (盛岡・ 藤田・岡寺・丹治）22，23) がおこなつた，7つの活動 セクターごとに固形廃棄物系と下水系の有機廃棄物を 算定する方式を採用した. $1 \mathrm{~km}$ グリッドごとの活動 量の分布を下に，セクターごとの原単位を用いて発生 分布を算定している（図7）.

\section{（2）循環技術の適合度分析の算定}

a）メタン発醳技術の適合地区の選定

メタン発酵適合度の分析においては，質的指標では 発生段階での含水率が $70 \%$ 以上の有機性廃棄物であ る下水污泥, 浄化槽污泥と家畜粪尿の全有機性廃棄物 に占める割合を算定した. これは文献 ${ }^{24)}$ により,メ夕 ン発酵槽に有機性廃棄物を投入する際には, 流動性や 

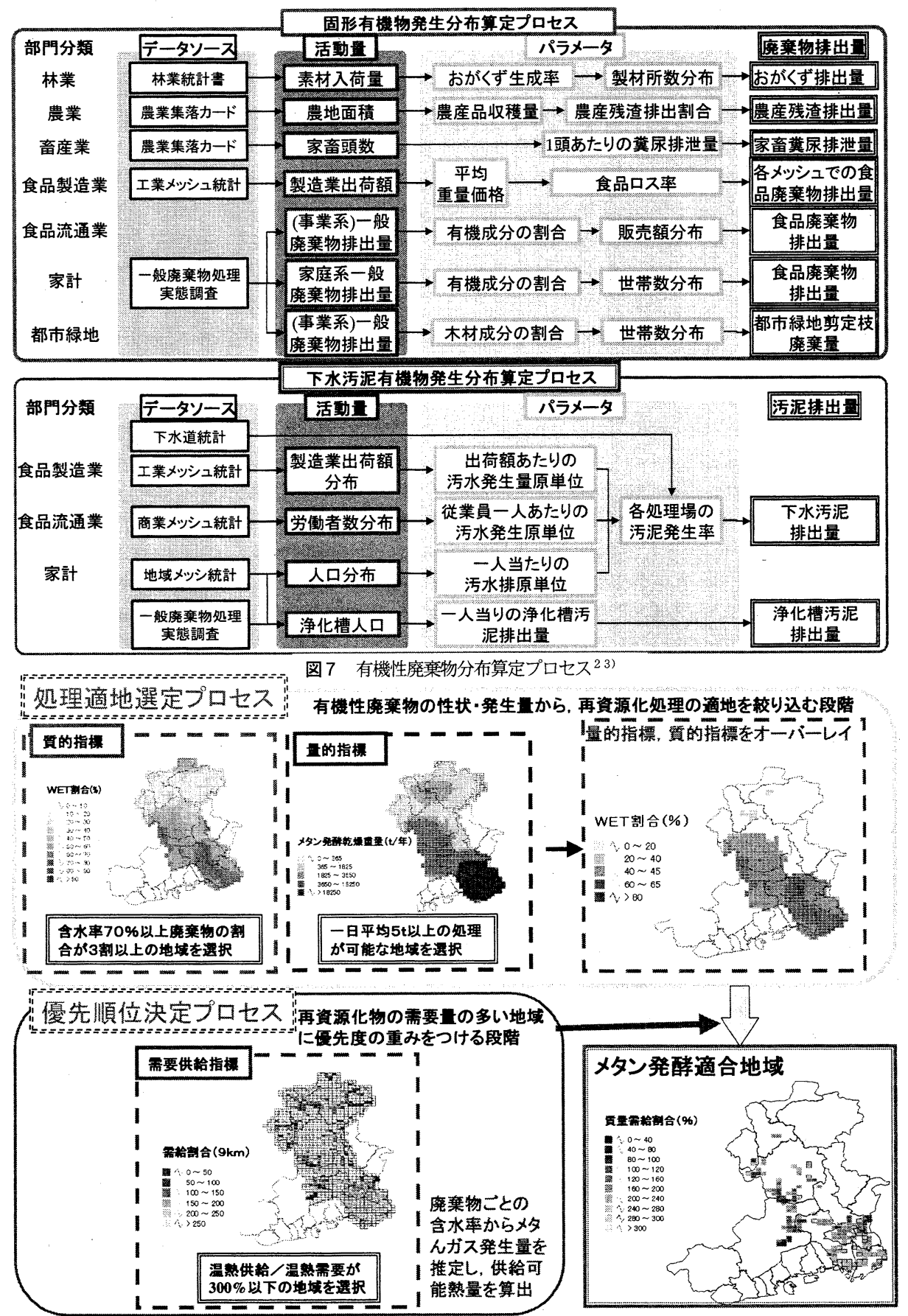

図8 メ夕ン発酵適合度分析

混和性の問題から廃棄物含水率を $70 \%$ 以上にまで高 める必要があるため, 前処理に必要なエネルギ一消費 が少ない有機性廃書物をここでは質的にメ夕ン発醉に
適した廃棄物として選択している. 続いて量的指標に よって，プラントでの実績值を参考に一日平均のメ夕 ン発醭槽投入予定物質乾燥重要量が $5 \mathrm{t}$ 以上の地域を 
選択した. 最後に需給指標に関しては, 燃料電池を経 由して発生する温熱量を熱供給ポテンシャルとして, その地域熱需要（住居系の暖房及び給湯における熱需 要)に占める割合が $300 \%$ 以下の地域を選択した. ここ で熱量の需給にのみ限定して需給指標を議論する理由 としては，熱量の場合供給可能範囲が限定され，地域
管理を行う上で電力よりも制約になると考えたためで ある. 以上の質的指標, 量的指標, 需給指標により得 られた地図をオーバーレイした結果を図8に示す.

\section{b）ガス化溶融適合度分析}

ガス化溶融適合度分析においては，質的指標では発

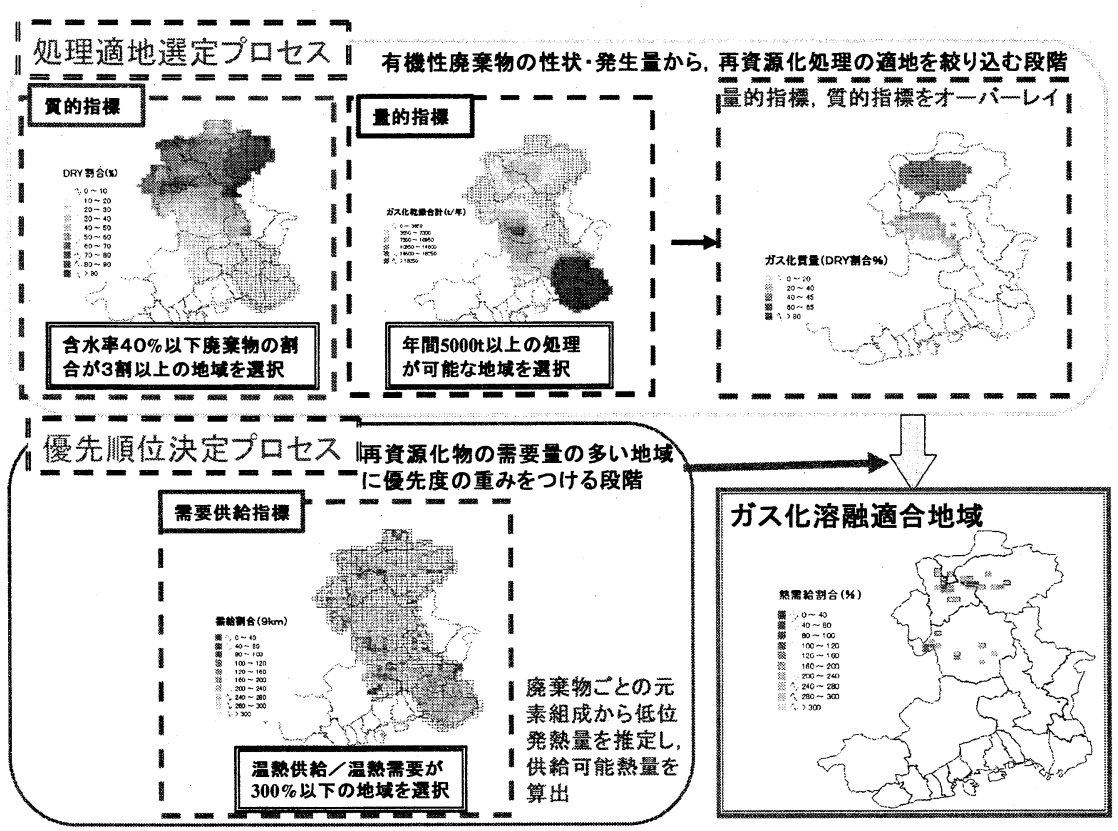

図9 ガス化溶融適合度分析

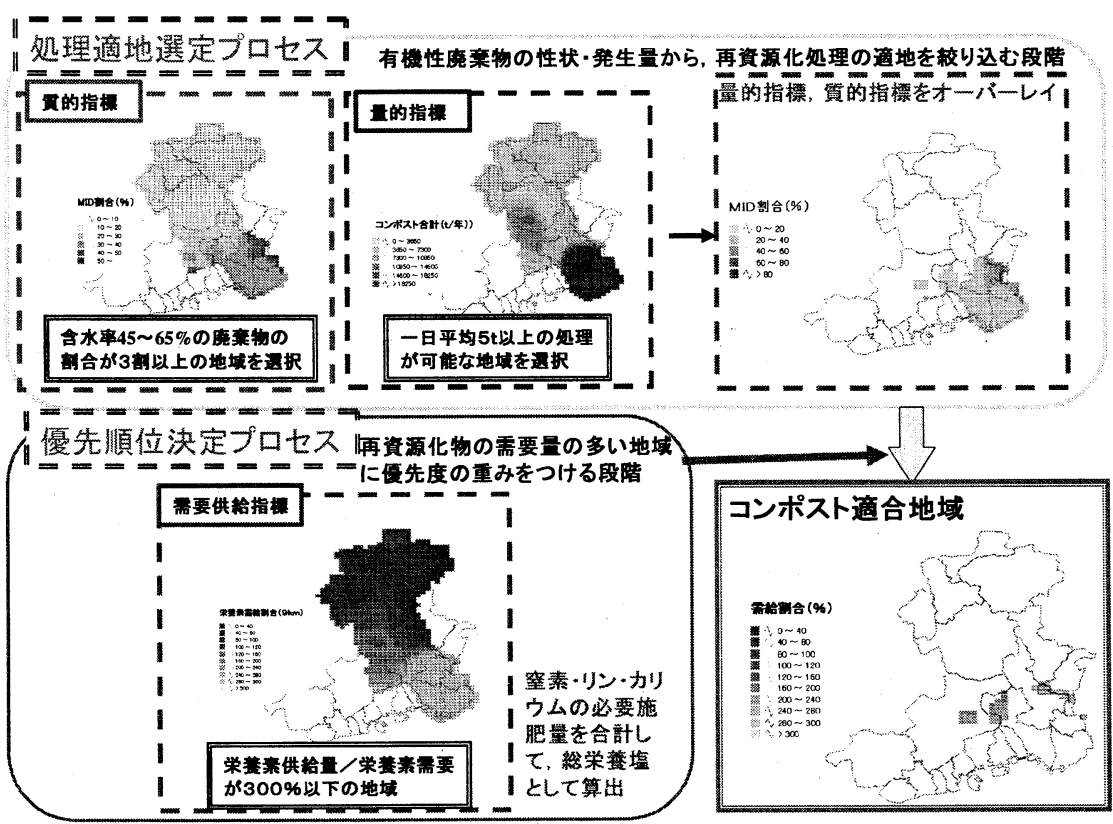

図 10 コンポスト化適合度分析 
生段階での含水率が $40 \%$ 以下の有機性廃棄物（林業, 作物系廃棄物, 緑地系廃棄物) の全有機性廃棄物に占 める割合を算定した。 これは含水率の高い廃棄物によ るエネルギー損失が技術選択に不利になる構造を考慮 している. 続いて量的指標について, プラントでの害 績值を参考に平均のガス化炉投入予定物質乾燥重量が $20 \mathrm{t}$ 以上の地域を選択した. 最後に需給指標に関し ては, ガスエンジンを経由して得られる熱量をポテン シャルとして, その地域熱需要（住居系の暖房及び給 湯における熱需要)に占める割合が $300 \%$ 以下の地域を 選択した.この手順は図 9 に示す.

\section{c)コンポスト化適合度分析}

コンポスト化適合度分析においては, 質的指標で発生 段階での含水率が $45 \sim 65 \%$ の有機性廃棄物（屍芥， 食品製造業, 食品流通業) の全有機性廃棄物に占める 割合を算定した.これは微生物反応である堆肥化にお いては水分の適值が存在している ${ }^{25}$ が, その值により 判断した. 続いて量的指標では, プラントでの実績値 を参考に一日平均のコンポスト化装置投入予定物質乾 燥重量が $5 \mathrm{t}$ 以上の地域を選択した. 最後に需給指標 に関しては, コンポスト化により得られる肥料成分で ある窒素・リン・カリウムの供給量（窒素揮散率は考 慮)の地域肥料成分需要に占める割合を算定した. 肥 料投入対象地としては, 田, 畑, 果樹園, 公園緑地と した. なお，全栄養素需要に対するコンポスト投入可 能割合を $50 \%$ と設定している。この手順は図 10 に 示す.

\section{（4）再資源化技術の適合地区の設定}

各再資源化技術の適合地区を重ね合わせた結果を図 11 に示す. 流域北部の篠山市周辺ではガス化溶融技 術による有機性廃棄物再資源化が有利であると示され， 同様にメ夕ン発酵は尼崎・西宮などの武庫川下流域及 び三田の周辺が候補地として示された. コンポスト化

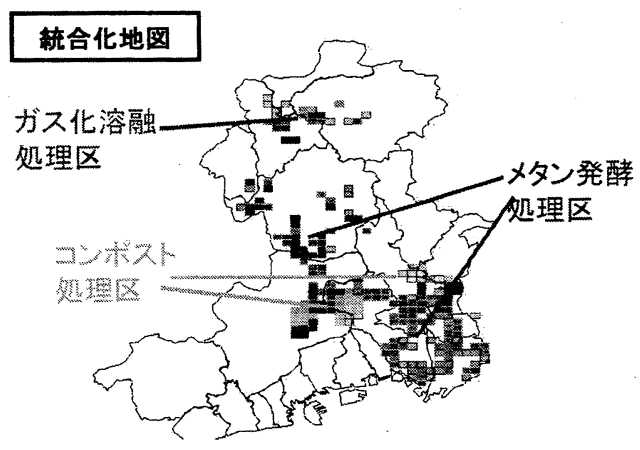

図 11 各指標の統合化
に関しては，神戸市北区の西部が候補地として示され ている.

続いて事業を実際に行うためのスケールとして，有 機性の廃棄物循環の最小単位を処理分区に設定しエリ アの決定を行った. 既存の各処理分区について,メッ シュごとの適合度が高いと判断されたメッシュの数に よって当該処理分区に対して適用する循環技術オプシ ヨンを設定した. 二つの技術に関する評価が同じ場合 には, 供給量/需要量の値が小さい方の再資源化技術 を選択することにした.

再資源化技術の適合地区を処理分区でと重ね合わせ た結果を図 12 に示す.

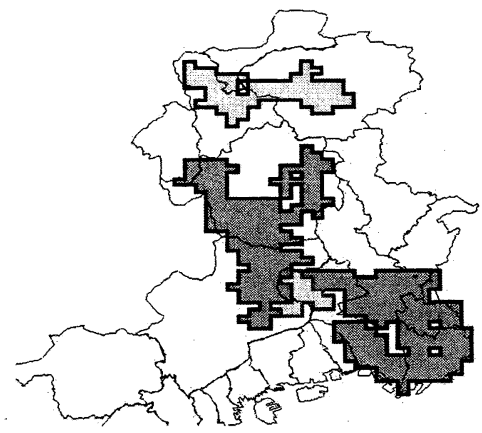

図12 処理分区との結合

\section{6. 流域環境影響削減効果の算定}

\section{1 ）代替的な政策プログラムの設定}

基盤適合度指標により導出される循環技術及びその 空間配置の環境負荷削減効果を比較評価するための代 替的な政策プログラムとして, 本研究では図 12 の処 理分区全域にメタン発酵及びガス化溶融を導入した政 策プログラムについて比較を行った.これらは計画立 案段階における技術選択及びエリア設定の論理を欠い た代替案として位置付けられる. 尚, 評価指標として は二酸化炭素排出量や最終処分量などが存在している が, 本研究では二酸化炭素排出量とした.

\section{2）再資源化施設立地点の決定}

図 12 の処理分区ごとに循環技術を導入した場合の 効果を算定するために, 需給指標導出の場合には考虑 しなかったプロセスエネルギーも考虑して計算を行う. また実質的な環境負荷削減効果を算定する場合, 電気 に関しては系統電力に投入することにより全量有効利 用されるものとするが, 温熱に関しては対象メッシュ 内のみの供給を考えた. この場合供給量が需要量を上 
回ることも考えられる. そのため実質的な環境負荷削 減効果に資する熱量は, 対象メッシュ内での温熱需要 量と供給可能量の小さい方である. 従って温熱を供給 するメタン発酵区及びガス化溶融区に関しては, 施設 立地点を決定する必要が生じる. そこで，1）で設定 した各代替案に対して, 施設立地点を以下のように設 定する.

\section{a）全域にメタン発醅を導入する政策プログラム}

流域全域にメ夕ン発酵技術を導入する場合, 最小規模 の循環区とした処理分区内の立地点としては, 現在のポ ンプ場の立地点とし, 処理分区内にポンプ場が存在して いない場合には処理分区内の最も標高の低い点とした.

\section{b）全域ガス化溶融施設を導入する政策プログラム}

全域にガス化溶融施設を導入する場合, 既存の焼却場 をガス化溶融システムの立地点とし, 各処理分区内の廃 菓物は最寄りのガス化溶融施設に搬入されるものとした.

\section{c）地域の適合度技術を採用する政策プログラム}

適合度分析を行った際のメタン発酵区においては, 全域にメタン発酵を導入した場合と同様, 各処理分区 内のポンプ場あるいは処理分区内の最も標高が低い地 点とした. ガス化溶融炉に関しては, ガス化区内部の 焼却場を立地点とした.

\section{3 ）代替プログラムの効果の比較}

1)，2）で述べた政策プログラムの二酸化炭素排出 量削減効果を比較する. その際, 再資源化物の供与を受 ける部門として民生家庭部門を想定し, その部門からの 二酸化炭素排出量の増減で比較を行った. 比較結果を図 13 に示す. これによると適合度分析により得られた再 資源化施設の配置を行う代替案と対象処理分区に一律に メ夕ン発酵施設を導入した場合の二酸化炭素排出削減量 が大きい. 効果がもっとも大きい適合度指標を用いた再 資源化システムを導入した場合, 1 万 $\mathrm{t}$-Cの炭素排出が 削減されるとの結果になつた. ガス化溶融技術に関して

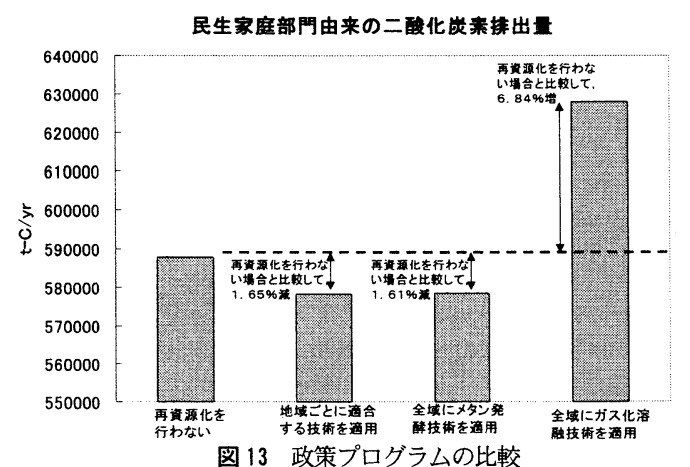

は，含水率の高い廃棄物を投入するため，その乾燥工 程に多大なエネルギーが投入されていることが結果に 反映された.

\section{7. 結論及び今後の課題}

本研究では，多様な地域特性を有する流域の管理に おいて有機性資源リサイクル基盤技術の地域との適合 度指標を提案し，その指標を用いることによって再資 源化施設立地候補選択システムを構築した. そしてそ の選択システムを実流域に適用することによって，二 酸化炭素を評価指標として環境への影響を評価した。 これによってケーススタディとして武庫川流域圏を設 定した場合では, 質的指標, 量的指標, 需給指標によ る適合度分析を行いそれに応じた施設立地を行うこと は，地域特性を考慮せず対象処理分区に画一的な処理 を施した場合と比較して, 環境負荷削減に有利である 可能性が存在することが示された. つまり適合度分析 から示される再資源化処理システムは, 同一処理領域 に一意的にメタン発酵処理を行った場合よりも若干二 酸化炭素排出量を抑制し，さらに一意的にガス化溶融 処理を行った場合と比較すると極めて大きな環境負荷 削減効果が得られることが分かった.

この結果からはガス化溶融処理技術の環境へのマイ ナスのインパクトが読み取れるが, これは, 本研究で は再資源化対象廃棄物として相対的に発熱量の低い有 機性廃棄物（下水污泥，时芥など）のみを対象とした ためであると考えられる. したがって本研究で取り挙 げた廃棄物の移動に伴い発生するプラスチックや紙く ずなど発熱量の高い廃棄物を再資源化処理対象物とし て追加することが今後の課題である.

本研究では, 土地利用や産業活動が面的に分布した 流域圏において, 有機物循環の観点から流域管理を行 う際のプロトタイプを構築し, その効果も確認するこ とができた. 以上のことから廃棄物の性状, 発生量, 再資源化物の需給などに代表される流域特性を考慮し た上で, 流域圏における多様な循環システムを構築す ることの重要性が認識された.

謝辞 : 本研究は平成 14 年度自然共生型流域圈·都市再 生技術研究 (代表 独立行政法人国立環境研究所渡辺 正孝水土壤領域長) の一環として行われたものである. 研究を遂行するにあたり, 国立環境研究所流域圈環境 管理研究プロジェクト研究者並びに兵庫県職員, 下水 道事業団職員の方々に多大なご支援・ご協力いただい た. ここに記して深く感謝する. 


\section{参考文献}

1）渡辺正孝：流域論とローカルガバナンスエコシステ ム・アプローチにもとづく持続可能な流域圈のための環 境管理，環境情報科学，Vol.31,No4,29-35,2002

2）増田貴則, 細井由彦, 相良拓男 : 家庭生ゴミ堆肥化とそ の利用を考慮した環境調和型市民農園による環境負荷 削減効果, 第13回廃棄物学会研究発表会講演論文集, $87 \cdot 89,2002$

3) 平井康宏, 高月紘, 村田真樹, 酒井伸一: 食品残渣を対 象とした循環・資源化処理方式のライフサイクルアセス メント, 第13回廃棄物学会研究発表会講演論文集, 87-89, 2002

4）盛岡通編 : 社会実験地での循環複合体のシステム構築と 環境調和技術の開発 研究実施最終報告書 第 3 編 農工連携による循環複合体の構築，2001年

$5 ）$ 松本亨, 鮫島和範, 井村秀文 : ディスポーザー導入によ る家庭の生ゴミ処理・再資源化システムの評価，環境シ ステム研究論文集, Vol.28,2000年10月

6）荒巻俊也，飯濱美夏，花木啓祐 : 東京都区部における民 生用エネルギ一供給由来の $\mathrm{CO}_{2}$ 排出削減可能性の検討 〜コジェネレーションシステムと清掃工場廃熱利用の 地域冷暖房システムの導入〜, 環境システム研究論文集, Vol.28,85-93,2000年10月

7）一ノ瀬俊明，川原博満：GISによる下水熱源地域熱供給 事業の地域別適正評価，土木学会論文集，No.643/VII $-14,29 \cdot 36,2000$ 年 2 月

8）原沢英夫, 福島武彦, 天野耕二 : 流域管理とその支援シ ステム（第 2 報），環境システム研究論文集， Vol.20,93-99, 1992年8月

9）益田光信 : KOMPOGASシステム（メタンガス化），環 境技術, Vol.29,No.9,669-675,2000年

10 ）神戸市ポートアイランド生ごみバイオガス化燃料電池 発電施設資料

11 ) 町井光吉, 新井徹, 津久井裕己, 篠崎功, 草間伸行 : 污泥消化ガス燃料電池発電システムの開発と実用化, 環
境研究, No.119,2000年

12 ) 高橋元洋, 草間伸行, 和田克也 : 燃料電池発電プラン トの燃料多様化への取組み, 東芝レビュー, Vol.53, No.8, 1998

13 ）京都府八木町八木バイオエコロジーセンタ一資料

14 ）矢田美恵子, 川口博子, 佐々木健 : 廃菓物のバイオコ ンバージョン, 地人書館, 1996年

15）ヒヤリング調査

16 ）尾前純也，小沢昇，清水益人，山田純夫 : 廃棄物ガス 化溶融設備からの熱分解ガスによるガスエンジン運軽 状況, 第13回廃棄物学会研究発表会講演論文集, 796-798, 2002

17 ）稲葉陸太, 花木啓祐：下水污泥と都市ごみのゼロエミ ッション, 環境システム研究一全文審査部門一, Vol.27, $365 \cdot 374 ， 1999$ 年10月

18）藤田賢二: 下水道工学演習, 学献社, 2001 年

19 ）生物系廃棄物リサイクル研究会 : 生物系廃棄物のリ步 イクルの現状と課題, 1998

20 ）平井康宏 : 温室効果ガスの視点から見た廃棄物処理シ ステムの評価〜生ごみを中心として〜，京都大学修士 論文, 1999年

2 1）小林久，佐合隆一: 窒素・リン肥料製造のエネルギー 消費・CO 2 排出のライフサイクル分析，第4回エコバ ランス国際会議講演集，2000

22 ）岡寺智大 : 環境負荷の排出と産業連関に着目した流域 管理に関する研究，大阪大学博士論文，2003年

23 ）丹治三則, 藤田壮, 盛岡通 : 流域圈のシナリ才誘導型 の施策立案と評価を支援する地理情報システムの設計と 運用に関する研究, 環境システム研究 (投稿中)

$24 ）$ 財団法人 食品産業センター: 資源循環型食品産業モ デル展開事業神戸地区ゼロエミッション推進委員会報告 書, 2002年3月

25 ）藤田賢二：コンポスト化技術一廃棄物有効利用のテク ノロジー一，技報堂出版，2000年

\section{INTEGRATED PLANNIGNG SUPPORT SYSTEM OF ORGANIC MATTERS RECYCLING INFRASTRUCTURE IN MUKO RIVER BASIN}

\section{Masayoshi KURISU, Tohru MORIOKA and Tsuyoshi FUJITA}

In managing the river basin, it is important to control the circulation of matters.So in this paper,we highliht the organic matters as the target for controlling the matters,and propose the system to aid the construction of organic matters recycling system in Muko River Basin.Concreatly we make three indicators ,quality-indicator,quantity-indicator,and demand-supply indicator,and evaluate the reduction effect of carbon dioxide by adapting the recyclyig technology on the shown recyle dictrict.According to the result,recycling system in river basin shown by the sutability index reduces more $\mathrm{CO} 2$ emission than the recycling system of one technology.So in managing the river basin,the importance of surveying the regional properties in deciding the recycling technology is shown . 